\title{
Contribution of Buddhist Mindfulness to the Transformation of Conflicts - Dependent Origination (paticca-samuppäda) and Deconstruction of Identity
}

\author{
Anja ZALTA*
}

\begin{abstract}
The article presents Buddhist mindfulness as a method for conflict transformation. On the basis of the concept of paticca-samuppāda (dependent origination) and anatta (nonself) the article (de)constructs the phases of identity formation. In Buddhist understanding, conflict is the result of defensiveness and misconceptions, and thus it is central to understand the mechanism by which the idea of "I" or "self" is established. The purpose of mindfulness is (among other things) to achieve a radical change in perception, which leads to "de-automatization" of mental mechanisms and suspends the identification with sensory and mental experiences that an individual calls a separate "I".

Since the Buddhist approach to conflict is based on a theory of cognition, this article emphasizes the individual effort needed for conflict transformation. Only later could or should this knowledge be applicable to a wider social environment, taking into account the diversity of socio-cultural conditions.
\end{abstract}

Keywords: mindfulness, Theravāda Buddhism, violence, conflict transformation, dependent origination (paticca-samuppāda)

\section{Izvleček}

Članek predstavi budistično čuječnost kot metodo za transformacijo konfliktov. Prispevek na osnovi konceptov paticca-samuppāda (soodvisen obstoj) in anatta (ne-jaz) (de)konstruira faze oblikovanja identitete. Konflikt je po budističnem razumevanju rezultat defenzivnosti in napačnih predstav, zato je ključno razumeti mehanizem, po katerem se vzpostavi ideja »Jaza«. Namen čuječnosti je (med drugim) doseganje radikalne spremembe v zaznavanju, ki prekine procese iz navade, s tem pa tudi istovetenje s senzoričnimi in mentalnimi izkušnjami, ki jih posameznik imenuje »Jaz«.

Anja ZALTA, Assistant Professor, Department of Sociology,

Faculty of Arts, University of Ljubljana, Slovenia.

anja.zalta[at]ff.uni-lj.si

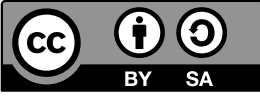


Budistični pristop k razumevanju konfikta temelji na teoriji kognicije, zato članek poudarja individualno prizadevanje za preoblikovanje konfliktov. Šele na podlagi individualnega razumevanja je mogoče to vedenje uporabiti v povezavi s širšim družbenim okoljem, pri čemer je treba upoštevati raznovrstnost družbeno-kulturnih pogojev.

Ključne besede: čuječnost, teravāda budizem, nasilje, transformacija konflikta, soodvisni obstoj (paticca-samuppāda)

\section{Introduction}

One of the greatest challenges in human history is understanding the causes and consequences of violence, and the continued presence of violence in the world raises the additional question of whether the only successful resolution to a conflict can be through violent acts. If a new paradigm should have a meaningful message for this violent world, then it must do more than simply condemn violence. It must be able to interpret its nature, its roots, and the possibilities for its transformation. In this context, what alternatives to violence can be offered by Buddhism?

Centuries of efforts to overcome violence can be traced throughout the entire Buddhist canon. The old Theravādic understanding of the causes of violence are complemented by modern approaches of socially engaged Buddhism, which use mindfulness as a method for both the individual as well as social transformation of conflicts. A number of socially engaged Buddhists (A.T. Ariyaratne in Sri Lanka, Tich Nhat Hanh from Vietnam, Sulak Sivaraksa in Tailand, and Western Buddhists, such as Robert Aitken, Ken Jones and Joanna Macy) support the view that social and spiritual transformations are not separate. To resolve social crises requires going to the roots of violence, and although Buddhist traditions have developed a number of social teachings, it is clear that the major emphasis of these is on individual spiritual transformation. ${ }^{1}$ One of the most important concepts of socially engaged Buddhism is the idea of inter-connectedness. Tich Nhat Hanh uses the term "Interbeing" (Nhat Hanh 2010) for this, which derives from the Buddhist idea of paticca-samuppāda (dependent origination), and this idea will be discussed in the following chapters.

In the current text, the concepts of conflict and violence (not only physical, but also structural and cultural) are used synonymously. According to most conflict theorists from the field of Sociology, conflict is an inevitable feature of society,

1 See Bond (2004); as well as: Queen and King (1996), Zalta (2013, 185-9). 
and social changes are caused by tensions between competing interests. However, it is essential to recognize the diversity of interpretations, different contextual meanings and ontological implications of conflict. The purpose of this paper is primarily to show the antagonistic dynamics of self-formation (identity process and its (de) construction) as a common trait, or so-called "turning point" in Buddhist interpretations of violence and conflict.

The research theses this work is based on are as follows:

- Since according to Buddhism conflict is the result of an identity-related antagonism, it is necessary to understand both the process of identity formation and its deconstruction.

- Because triggers for violence are present in one's mind, it is necessary to introduce a method which brakes with one's usual ways of thinking about and reacting to the object(s) of consciousness.

The main purpose of the article is to think about the options offered by the Buddhist canon and its interpretations with regard to the issues outlines above. However, it is necessary to warn about the very broad nature of this topic, and thus to note that this article is just a preliminary work opening new horizons which require more extensive research and application.

\section{Buddha's "Middle Path" and the Characteristics of Existence}

In Buddha's time there was a debate on the question of the relationship between the individual and the social aspect of human existence. Various ascetic schools presented their opinions, which were not based on academic theories and speculations, but on the experience of yogis and meditators. We can roughly divide the resulting views into two groups, recognised as "Materialists" and "Substancialists" (Edelglass and Garfield 2009,13-61). Materialists reject the idea of a metaphysical soul, and believe that our true essence can be detected only on the basis of empirical observation of the physical body, which is destroyed at death. In contrast, Substancialists argue that one's individual nature can be explained by assuming the soul as a separate entity, different from the body. The permanent metaphysical " $\mathrm{I}$ ", which stays in the body, takes another body after death. is view is also called "eternalism", believing that the soul is eternal.

Buddha adopted a middle path by which he defined not only the nature of the individual, but also his/her social integration. He presented three characteristics of existence: Dukkha - the unsatisfactoriness of life (translated also as discomfort, suffering) is defined by anicca--impermanence, which is the central 
idea of Buddhism, and represents a rebuke to the materialist position, since all things are constantly changing, including our physical bodies. Finally, anattanon-self, the "I" or an "individual" does not consist of a static soul, but of the changing states of consciousness. It is essential to understand human existence not as a static entity, but as a process, and this understanding should help us strengthen our ties with the wider society. The idea of the interconnectedness/ dependent origination ( $p a t i c c a-s a m u p p a \overline{d a}$ ) is especially important here, since all objects and subjects are dependent on each other and appear in a wider network of co-existence.

The concept of dependent origination will be analysed later in this article, but let us first explore the Theravādic understanding of violence and the genesis of a conflict.

\section{Theravāda Buddhism and Violence}

By examining three key texts that numerous authors, especially Harris (1994) have noted deal with the question of violence, i.e. the Dhammapada, the Sakkapanha Sutta, and the Cakkavattisihananda Sutta, it is possible to demonstrate that Theravāda Buddhism has a strong basis in denouncing any kind of violence. In short, violence in word, thought and action is to be eschewed, as while it obviously hurts the victim, it also does not bring any happiness to the person who is violent. As wisely stated in the Dhammapada:

Victory breeds hatred, The defeated live in pain.

Happily the peaceful live,

Giving up victory and defeat.

(Dhp.v. 201)

The motivation to avoid violence and protect the lives of others comes from reflection on the fact that everyone has a similar position toward their own life. The idea of paticca samuppāda (inter-connectedness) and the understanding of co-responsibility arise from this insight: there is nothing in this world that is independent of everything else. Moreover, because of this interdependent nature we cannot overlook the various forms of violence that are subject to other factors. When Buddha spoke about the causes and solutions to violence, his approach depended on the prevailing conditions in a specific situation. ${ }^{2}$

2 For example, in Cakkavatti Sīhanānda sutra he talks to rulers about social issues, and highlights social and economic causes rather than psychological factors. 
In general, Theravāda Buddhism holds the opinion that extreme violence, such as war and conflict, arises due to sensual desires. Ignorance, craving $(\tan h \bar{a})$ and greed (lobha) are thus seen as the common roots of violence. On analysis, two broad and mutually interdependent conclusions emerge from this point of view: (1) violence arises from an individual's unwholesome state of mind, and (2) violence arises from unsatisfactory social and environmental conditions, caused by the unwholesome state(s) of mind(s) of other(s).

\section{The Genesis of the Conflict and Its Link to Mental Factors}

Buddhist textual sources contends that behaviours and structures of conflict originate from the human mind; that the deeper causes of conflict lie in mental processes within each being. We learn from certain Buddhist texts that suffering in the world can be addressed through transformations of mental processes, and that mental states can be worked with, even in the most difficult circumstances. There is a specific analysis of conflict found explicitly in the Theravāda literature, however, for a wider perspective we need to review the more foundational teaching of dependent origination.

Gnanarama (1998) presents teachings from the Pali Sakkapanha Sutta, recorded as a dialogue between the Buddha and the deity Sakka, who asks the Buddha:

What is the reason that prompts the gods, men, asuras, gandhabbas and other classes of beings to be hateful, harmful, and envious of one another, causing them to continue to live in conflict despite the fact that they wish to live all time without those evil thoughts?

The Buddha's reply is an explanation of the causal genesis of conflicts for a psychological point of view:

Envy (issa) and avarice (macchariya) are conditions for > conflicts.

Things dear (piya) and not dear (appiya) are conditions for > envy and avarice.

Desire (chanda) is condition for > things dear and not dear

Thought conception (vitakka) is condition for > desire

Concepts tinged with the mind's tendency (papancasanna samkba) to prolifetation condition > thought conception (Gnanarama 1998, 204).

Therefore, concepts with the mind's tendency to "proliferation" are the conditions for > thought conception, this is then a condition for > desire, which is a condition 
for regarding > things dear and not dear, which conditions > envy and avarice, which conditions $>$ conflict.

The Buddha's analysis has conflict arising dependent on mental processes rooted in a person's wrong attitudes towards "perception”. Conflict in Buddhist understanding is the result of defensiveness and misconceptions, and thus it is central to understanding the mechanism by which the idea of "I" or "self" is established. According to Buddhism, this idea can lead to obsession, enslaving the individual and causing the destruction of society.

In Buddhism, what we regard conventionally as a "person" is analysed into five aspects or "groups of grasping" (upādāna-khandha's): rūpa, "material shape" or "form"; vedanā or "feeling"; sañ $\tilde{a} \bar{a}$, "cognition", which processes sensory and mental objects, so as to classify and label them (that is the recognition and interpretation of sense inputs); sankhära's or "constructing activities", a number of states which initiate action or direct, mould and give shape to character (the most characteristic "constructing activity" is cetanā, "will" or volition which is identified with karma); and viññāna, (basic and sensory) consciousness. Yet all of these phenomena are transitory, since the "three marks" of all conditioned phenomena are that they are impermanent (anicca), unsatisfactory (dukkha), and non-self (anatta). "Because they are impermanent and unsatisfactory, they are to be seen as non-self: not a permanent, self-secure, happy, independent self or I. They are empty (suñña) of such a self, or anything pertaining to such a self" (Harvey 1990, 53).

This defines the origin or cause of suffering (dukkha), which must include conflict. A sense of "self" springs from delusion based on the failure to perceive the world as it actually is. This "I" notion is a priori central to the analysis of conflict in thoughts and actions. It springs from a desire to identify and claim some part or parts of the universe as one's own, thinking "this is mine, I am this, and this is my self", as opposed to anyone else's. The desire to construct a "self" or personal identity leads to selfish concerns.

Caroline Brazier stated:

When I feel that what I regard as my self, that what I regard as by rights mine is in danger of being taken from me, I become angry, frustrated, and fearful; I may even be driven to violence and kill. And yet disease, old age and death for sure will take from me all that I have regarded as minebody feelings, ideas, volitions, and mind. (Brazier 2003, 147)

Conflict(s) then stem from the felt need to defend what is seen to be one's own or to achieve personal gain; a person can thus become the victim of obsessive actions, 
thoughts and inclinations, with war and struggle arising from the conflict of views (ideologies and related concepts).

Regardless of the cultural context, the dynamics of a conflict stays the same: a strong antagonism between "us/me" and the "other/not me/not mine" appears. It could be an external other defined by religion, ethnicity, gender, skin colour of shape of the nose (as in the case of the 1993 Rwanda genocide). It can also be an "internal other", a part/characteristic of "me" that I dislike, that I perceive as a burden in a process of self-actualization.

To overcome the delusion of the "otherness" as something totally different, we need concepts to challenge the established mind-sets. More generally as a foundational analysis Buddhism offers the concepts of inter-connectedness, dependent origination, non-self, unsatisfactoriness, and impermanence, any one of these can serve as a starting-point for the application of new paradigms. Before embarking on a journey of conceptual clarification and identity deconstruction, it is important to make more precise the Buddhist position regarding the understanding of a conflict.

\section{The Concept of Dependent Origination (paticca-samuppāda) and the Problem of "Non-self" (anatta)}

According to Izutsu, Western thought derives mainly from the Platonic-Aristotelian system, which is based on the category of substantia, in contrast to Buddhist philosophy, which is "ontologically a system based upon the category of relatio"; for Aristotel, knowing an object demands knowledge of its "essence", its fixed and determined inner substance. Yet according to the Buddhist worldview, knowledge cannot be attained as long as an object's fixed inner substance is sought. (Izutsu 1977, 23)

As Kuttner presents in addition to Izutsu's analysis, according to the principle of dependent origination,

any given situation is a set of connections and relations in which separate entities arise, entities that through a process of abstraction we grasp as having the characteristics of continuous separate substances. Seeing entities as continuous, separate substances is an abstraction that results from observing a situation from an external perspective, and from ignoring the process of dependent origination as it occurs in the moment. (Kuttner 2002, 62) 
In doing so, we create notions of entities that we perceive to be existing separately from their arising, having a substantial and permanent inner nature with which, as Kuttner said, "they" enter a process of interaction with "another"-a similar substantial and permanent entity (Kuttner 2012, 63). This illusion, according to the Buddhist worldview, relates not only to the perception of human beings as having a substantial and independent "self", but to the perception that any entity-whether object, idea, or feeling-is a separate, self-substantive entity. To understand the problem of identity and self-formation, it is thus necessary to study closely the Buddhist understanding of the "dependent origination" (paticca-samuppāda).

\section{Mahä-nidāna Sutta and the Analysis of Dependent Originations}

The basic reading for the following chapter is the one of the most profound discourses in the Pāli canon, Mahā-nidāna Sutta: The Great Causes Discourse (Bodhi 1984). This sutta presents a teaching of dependent origination, paticca-samuppā$d a$, also called "dependent co-arising", "conditioned co-production", "casual conditioning", and "casual genesis". Paticca-samuppāda is a basic teaching of Buddhism, and while Buddha himself did not set forth the related doctrine, Piyadassi claimed that

one who understands the philosophical and doctrinal significance of dependent origination certainly understands that the twelvefold dependent origination, both in its order of arising and ceasing is included in the Fourth Noble Truth (Piyadassi 2008, 5).

The first part of the sutta addresses the factors of dependent origination, tracing them down to mutual dependency. The second part of the discourse deals with the teaching of non-self (anatta), and shows how this dependent origination gives focus to this teaching in practice. The first chapter of the second part of the sutta is dedicated to the delineations of a self, followed by the non-delineations of a self, assumptions of a self, the seven stations of consciousness, and eight emancipations. As Mahā-nidāna Sutta states in the section on the non-delineations of a self, it is possible for the mind to function without reading a "self" into experience.

Since Buddhist psychology teaches us that our mentality is conditioned, it is first necessary to explore how this occurs.

The formula of Dependent Origination in the Mahā-nidāna Sutta (DN. 11. 5571) (in modified version) runs as follows: 
ignorance $\rightarrow(2)$ volitional formations (constructing activities) $\rightarrow$ (3) (discriminative) consciousness $\rightarrow$ (4) mentality-materiality $\rightarrow(5)$ the six-fold bases $\rightarrow$ (6) contact (sensory stimulation) $\rightarrow$ (7) feeling $\rightarrow$ (8) craving $\rightarrow$ (9) clinging (attachment $) \rightarrow(10)$ becoming $\rightarrow$ (11) birth $\rightarrow$ (12) death ... ${ }^{3}$

Let us look more closely to these conditions:

(1) Ignorance or delusion (of anicca, anatta, dukkba, among other things) is one of the root causes of all unwholesome actions, which give rise to (2) volitional formations. The term sankbāra applies to all conditioned things, all things that come into being as the effect of causes and conditions, and which themselves act as causes and conditions in turn to give rise to other effects (all actions, physical, verbal and mental, which brings about good or evil reactions (kusala-akusala kamma). (Gorkom 2010, 73)

"Samskaras (sankhārā) are the constructions that people build in their minds as they try to make their experience yield evidence to support their self-construct. Because they hold on to the deliberately limited view, they build samskaras."(Brazier 2003, 184) On this depends (3) consciousness (viññana), which is sometimes translated as "distinctive knowing" or "discriminative consciousness" (McConnell 1995). Consciousness is the ordinary mind that separates the world into "me" and "everything else". This is where the division into what is "mine" and what is "not mine" occurs. At this stage "the other" is formed in the consciousness. Consciousness gives rise to (4) mentality-materiality, nāma-rūpa. The term nāma here stands for the mental states (cetasikas). The so called "being" or "person" discussed above is a nama-rüpa (composed of five aggregates or groups, namely, physical body, feeling, perception, volitional formation, and consciousness (rüpa, vedanā, sañña, sankhārā and viññana). At this stage "me" grants name and form to both oneself and the discriminated "other" in order to organize it/them in a manner that would fit the self-picture already created. In dependence on this arrangement, (5) the six-fold base then arises: the five physical sense organs-eye, ear, nose, tongue, and body-and the mind base (manayatana) (five kinds of sense consciousness and many kinds of mind-consciousness). As analysed by Brazier, each sense tends to be attracted to things to which it has been attracted in the past and repulsed by things it has previously avoided, thus creating an illusion of continuity (Brazier 2003).

Dependent on this six-fold base there is then (6) contact, "invested contact" or "self-interested contact". This is the actual contact of the all-ready "me" or "I"

3 It is important that this linear succession should not be taken literally, since it is not a theory of cause and effect in a narrow sense of "A causes B". More correctly, A makes it possible for B to happen, but sometimes $\mathrm{C}$ could make $\mathrm{B}$ possible, too. 
with what is perceived as the "Other", which does not match the idea of "me". External to one's material body, there are the corresponding five sense objectsform, sound, smell, taste and tactile objects—and beyond this the mental objects. Dependent on contact arises (7) feeling, which is six-fold: feeling born of visual contact; feeling born of sound contact; feeling born of smell contact; feeling born of taste contact; feeling born of body contact, and feeling born of mental contact.

Dependent on feeling arises $(8)$ craving $(\tan h \bar{a})$. All forms of appetite are included

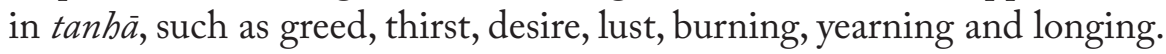

Dependent on craving arises (9) clinging or attachment, upādāna. Piyadassi listed attachment to sensuous pleasures or desires (kāma-upādāna); attachment to wrong and evil views (ditthi-upādāna); attachment to mere external observances, rites and rituals (silabbata-upādāna); and attachment to self or a lasting soul-entity (attavāda-upādāna) (Piyadassi 2008,6).We can cling or be attached to certain objects, as well as identities, thoughts, and perceptions.

Dependent on clinging arises (10) becoming (bhava). After a certain pattern is created, and as a result of the wish to preserve it as a characteristic that describes one's behaviour, certain mental structures are formed. The idea of who "I am" as an independent "self" comes to mind.

Dependent on becoming arises (11) birth (jati), which refers to the psychological birth of the substantive self as an independent, separate entity. Dependent on birth arises (12) aging and death (jarämarana), and with them come sorrow, pain, grief, and despair. However firm it may seem, all that is born will also decay and die. According McConnell's psychological interpretation,

we constantly create mental pictures, crave to preserve them, and then are compelled to see them decay and die. It is the decay of our concocted self-picture, a picture in which much has been invested in creating, and therefore its decay brings frustration, suffering, and disease. (McConnell $1995,74)$

\section{Contribution of Mindfulness to the Transformation of Conflicts}

If we go back to the formation of a "self" in Buddhist terms, we have seen that the first skandha is materiality (rüpa). How can we understand it in the reference to self-formation? We commonly impose distortion on an object, since we see in the object signs that lead us to construe a self, an "I". The object thus become an indicator of the self and is called namma-rūpa, "named object". It becomes a 
conditioned phenomenon, something that one sees in a distorted and ultimately self-interested way. In this case a person does not simply see the object as it is, but only as a signpost for an aspect of one's self, as a "brickstone" for self-identification. At this point craving has been aroused, since one tends to seek out things that reinforce this sense of identity.

Having just said that, the above mentioned process is combined with the second skandha, vedana, "feeling(s)" or "reaction(s)", which has three possible forms: attraction, aversion and neutrality as an instant response, aroused from sensory contact an immediate reaction. With the third element in the skandha process, sañ $\tilde{n} \bar{a}$, "cognition", associations come up. Assisted with samskaras, "mental formations" as mental structures result from the traces we have laid in the past. This is where an "individual" becomes hooked in a process of identity building. Patterns of habitual energy are called samskaras. Some samskaras are so deeply worn that we are repeating the behaviour again and again. They become habitual reactions.

These habitual reactions are mistakenly understood as fixed "self", because they are combined with the final skandha, viññana, "consciousness", which is associated with self-investment/self-actualization, as an outcome of a skandha process: the mind that seeks confirmation of the self's existence, separates the world into "me" and "other(s)" or "me" and "the rest".

As we cling to particular patterns of response and behaviour, we start to create those mental structures that we think of as the "self". The process of conditioning creates a constellation of behaviours and perspectives to which we become attached and identify with these patterns.

Backed up with the deep understanding of "three marks" of all conditioned phenomena (annica, anatta, dukkba), the Buddhist critique of the notion of the "self" rests on the claim that we never in fact experience an unchanging self. In other words, the idea that there is an eternal, unchanging "I" is supported by a failure to understand the interdependent coexistence of all phenomena.

To conclude the chapter with Buddha's insight from the Māhanidāna Sutta (DN $55,32)$ :

From the time, Ananda, when a monk no longer regards feeling as self, or the self as being impercipient, or as being percipient and of a nature to feel, by not so regarding, he clings to nothing in the world; not clinging, he is not excited by anything, and not being excited he gains personal liberation, and he knows: "Birth is finished, the holy life has been led, done was what had to be done, there is nothing more here" (Walshe 2012, 227-8). 


\section{Conclusion}

Mindfulness can be described as a direct, non-reactive observation, a wakefulness, characterized by moment-to-moment awareness of perceptible mental states and processes that includes continuous, immediate awareness of physical sensations, perceptions, affective states, thoughts, and images. Exercises focused on mindfulness are believed to broaden attention, enhance positive emotions, and lessen negative emotional states; they are also seen to be able to shift a person' basic view of themselves in relation to others. Based on the understanding of the three characteristics of all conditioned phenomena (dukkha, anatta, anicca) the individual gradually realize that mental and sensual activities are not the firm unchangeable "me" of "self" or "I". It is believed that practicing mindfulness leads to "de-automatization" of mental mechanisms, facilitates the development of concentration and insight, reinforces positive emotions and minimizes negative emotional states. Despite these psychosocial benefits, it must not be forgotten that the practice derives from the Buddhist tradition, and that efforts to apply it in order to achieve personal prosperity and well-being cannot and should not replace the ethical conduct that causes compassion and empathy, and then reshapes a person's internal and external conflicts. Buddhism aims to lay down a form of mental culture that lessens the mind's tendency towards violence. The right understanding of "I" or "self" as a process, and not as a fixed (id)entity, combined with the right understanding of the non-duality of beings, could thus be a helpful tool for conflict transformation.

\section{References}

Brazier, Caroline. 2003. Buddhist Psychology: Liberate Your Mind, Embrace Life. London: Robinson.

Bodhi, Bhikkhu. 1984. The Great Discourse of Causation: The Māhanidāna Sutta and Its Commentaries. Kandy: Buddhist publication Society.

Bond, George D. 2004. Buddhism at Work, Community Development, Social Empowerment and the Sarvodaya Movement. West Hartford: Kumarian Press.

Cakkavatti - Sihananda Sutta. Accessed March 3, 2015. http://www.basicbuddhism.org/index.cfm?GPID=29.

Edelglass, Willam, and Jay Garfield. 2009. Buddhist Philosophy: Essential Readings. Oxford: University Press.

Kuttner, Ran. 2012. "From Positionality to Relationality: A Buddhist-Oriented Relational View of Conflict Escalation and Its Transformation." Peace and Conflict Studies 20 (1): 58-82. Accessed June 17, 2015. http://nsuworks.nova. $\mathrm{edu} / \mathrm{cgi} /$ viewcontent .cgi? article $=1144 \&$ context=pcs. 
Gethin, Rupert. 1998. The Foundations of Buddhism. Oxford and New York: Oxford University Press.

Gnanarama, Pategama. 1998. Aspects of Early Buddhist Sociological ought. Singa-pore: Ti-Sarana Buddhist Association.

Gorkom, van Nina. 2010. The Conditionality of Life, An Outline of the Twenty-Four Conditions as Taught in the Abhidhamma. London: Zolag.

Harris, Elizabeth J. 1994. Violence and Disruption in Society, A Study of the Early Buddhist Texts. Kandy: The Wheel Publication.

Harvey, Peter. 1990. An Introduction to Buddhism, Teaching, History and Practice. Cambridge: Cambridge University Press.

Izutsu, Toshihiku. 1979. Toward a Philosophy of Zen Buddhism. Tehran: Imperial Iranian Academy of Philosophy.

McConnell, John A. 1995. Mindful Mediation: A Hand Book for Buddhist Peace-makers. Kandy: Buddhist Cultural Centre.

Nhat Hanh, Tich. 2010. Together We Are One: Honouring Our Diversity, Celebrating Our Connection. Berkley: Parallax Press.

Queen, S. Christopher and Sallie B. Queen, eds. 1996. Engaged Buddhism, Buddhist Liberation Movement in Asia. New York: State University of New York Press.

Piyadassi, Thera. 2008. Dependent Origination. The Wheel Publication vol. 15. Kandy: Buddhist Publication Society.

The Dhammapada. 1985. The Buddha's Path of Wisdom, translated by Acharya Buddharakkhita. Kandy: Buddhist Publication Society. Accessed June 20, 2015. http://www.buddhanet.net/pdf_ le/scrndhamma.pdf.

Zalta, Anja. 2013. "The Sarvodaya Shramadana Movement and Its 'Dual Awakening' Concept." In Faith in Civil Society: Religious Actor at Drivers of Change, edited by Heidi Moknes and Mia Melin, 185-9. Uppsala: Uppsala University, Centre for Sustainable Development.

Walshe, Maurice. 2012. The Long Discourses of the Buddha: A Translation of Digha Nikay. Boston: Wisdom Publication. 